\title{
Light and Electron Microscopic Studies on Mandibular Organ in Relation to Female Reproductive Cycle of the Freshwater Crab
}

\section{Travancoriana Schirnerae}

\author{
Sudha Devi AR ${ }^{1 *}$, Aswani $\mathrm{A}^{1}$ and Bhadravathi Kenchappa CS $^{2}$ \\ ${ }^{1}$ Department of Zoology, Mary Matha Arts \& Science College, India \\ 2Department of Neuropathology, National Institute of Mental Health and \\ Neurosciences, India
}

*Corresponding author: Sudha Devi Arath Raghavan, Associate Professor (Retired), Department of Zoology, Mary Matha Arts \& Science College, Wayanad, Kerala 670 645, India, Tel: +91 9947163 686; Email: arsudhadevi@gmail.com

\section{Research Article \\ Volume 3 Issue 3}

Received Date: October 02, 2019

Published Date: October 14, 2019

DOI: $10.23880 /$ ijoac- 16000173

\section{Abstract}

This study elucidated the light and electron microscopic observations on mandibular organ in relation to the female reproductive cycle of the edible freshwater crab Travancoriana schirnerae. Results indicated that the gland underwent correlative changes in accordance with the phases of reproduction, with highest activity during the reproductive phase and least during the pre and post-reproductive phases. During the reproductive phase, the gland cells and their nuclei exhibited hypertrophy and the cytoplasm displayed numerous extraordinarily hypertrophied, unusually dense, polymorphic mitochondria with increased number of transverse tubular cristae, prominence of Golgi with swollen cisternae, vesicles and dense granules, swollen tubular cisternae and vesicles of rough and smooth endoplasmic reticulum, rich free ribosomes and electron dense secretory granules, characteristic of high cellular activity in connection with the synthesis of methyl farnesoate, the secretory product of the mandibular organ. The abundance of hemocytes, in particular, granular hemocytes enclosing electron dense granules of varying sizes, shapes and density in the wide hemolymph channels and sinuses during the reproductive phase suggested their role in the storage and transport of the secretory product of the gland.

Keywords: Freshwater Crab; Mandibular Organ; Reproductive Cycle; Travancoriana schirnerae; Ultrastructure

Abbreviations: CW: Carapace width; GSI: Gonadosomatic index; MF: Methyl farnesoate; MO: Mandibular organ; RER: Rough endoplasmic reticulum; SER: Smooth endoplasmic reticulum.

\section{Introduction}

The mandibular organs (MO) are paired, ductless, ectodermally derived endocrine glands, positioned at the 


\section{International Journal of Oceanography \& Aquaculture}

base of the adductor muscle of the mandibles in crustaceans. It was first described by Le Roux [1] in the crab Carcinus maenas. Several studies suggested its role in the regulation of moult and reproduction in crustaceans [2-4]. Fine structural studies by Byard, et al. [5] and Hinsch and Al Hajj [6] revealed that the MO cells resembled steroid or lipid synthesizing cells. Byard, et al. [5] suggested that the MO which played a gonadotropic and ecdysiotropic role by controlling reproduction and moult in crustaceans is analogous to the corpus allatum of insects. Couch, et al. [7] reported the presence of progesterone-like substance in the MO of Homarus.

The histology and ultrastructure of MO were described in a number of crustaceans [1,2,4,8-12]. Buchholz and Adelung [13] studied the ultrastructure of MO of crabs Hemigrapsus nudus and C. maenas. Hinsch [14] observed that the MOs were found active during vitellogenesis in $C$. maenas and Libinia emarginata. Taketomi and Kawano [15] described the fine structure of MO of the shrimp Penaeus japonicus. A detailed structure of Fenneropenaeus indicus MO was provided by Vijayan and Diwan [16]. Sheng Li and Wei Xin [17] noticed a parallelism between the structural changes in MO and ovarian maturation in Procambarus clarkii. The histology and ultrastructure of MO in P. chinensis was investigated by Sheng Li, et al. [18]. Nagaraju, et al. [19] observed a positive correlation between the MO and body weight, sex, moult stage and reproduction in the rice field crab Oziothelphusa senex senex. Light and electron microscopy of the MO of the mangrove crab Sesarma quadratum during different stages of development of the ovary were elucidated by Syama [20]. Sarika, et al. [21] noticed that the activity of MO was in accordance with the reproductive season in Paratelphusa sp.

The MO synthesizes and releases a sesquiterpenoid, methyl farnesoate (MF), analogous to the juvenile hormone III of insects. Very little is known about the role of MF in crustaceans until its analogy with JH III of insects was established [10,22,23]. In vitro and in vivo experiments in C. maenas, L. emarginata and P. clarkii have demonstrated the relation between MF production and ovarian maturation in decapods [22,24-26]. In vitro incubation of shrimp previtellogenic oocytes with various concentrations of MF significantly stimulated their growth into vitellogenic oocytes [27].

The edible freshwater crab Travancoriana schirnerae, commonly distributed in the wetlands of Wayanad, Kerala, forms an important source of lean protein for the local tribal communities. Though literature is plenty on the relation between vitellogenesis and MF titer, direct experimental evidences on the role of MO in female reproduction is rather scarce. At this juncture, the current investigation on light and transmission electron microscopy of the MO in relation to pre-reproductive, reproductive and post-reproductive phases of female $T$. schirnerae, which is totally lacking in freshwater brachyurans, is undertaken. Outcome of this research may help in a better understanding of the nature of secretions of the gland and its cyclicity in production in relation to the female reproductive cycle of freshwater crabs.

\section{Materials and Methods}

Adult female crabs (carapace width (CW) 4-5cm) were collected from the paddy fields of Ondayangady, Wayanad district of Kerala $\left(11^{\circ} 49^{\prime} 20.3^{\prime \prime} \mathrm{N}\right.$ and $76^{\circ} 01^{\prime} 47.1^{\prime} \mathrm{E}$ ), India for one year (January to December, 2018). The animals were accomplished to the laboratory conditions for 3-4 days. They were maintained in plastic tubs and the water in the tubs was changed daily. The animals were fed ad libitum with cooked beef liver, boiled egg, pulses and decayed leaves. The temperature and photoperiod conditions were adjusted to $25 \pm 2^{\circ} \mathrm{C}$ and $12 \mathrm{~L}: 12 \mathrm{D}$ respectively. The animals were grouped into prereproductive, reproductive and post-reproductive phases based on morphological characteristics such as colour of the ovary, oocyte diameter and gonadosomatic index (GSI). The body weights and wet weights of ovaries were recorded to calculate the GSI. For measurement of oocyte diameter, around hundred oocytes/ovary were chosen randomly and measured their diameters using a calibrated ocular micrometer. The following equation was used to calculate the GSI.

\section{GSI = wet weight of the ovary / body weight $\mathrm{x} 100$}

For light and ultrastructural studies, the MO from adult females in various phases of reproduction was dissected out under a trinocular stereozoom dissection microscope. The length and width of the organ was recorded using a calibrated ocular micrometer. The organs were immediately fixed in $3 \%$ glutaraldehyde (containing $0.1 \mathrm{M}$ phosphate buffer of $\mathrm{pH} 7.2$ ) for 24 hours, washed twice in the same buffer, postfixed in $1 \%$ osmium tetroxide for $1 \frac{1}{2}$ hours and dehydrated in ascending grades of ethanol. After clearing in propylene oxide, the tissue was left in a mixture of propylene oxide and araldite resin (1:1) overnight, and later transferred to propylene oxide and araldite mixture 1:3 ratio followed by pure araldite for 2-3 hours. Tissues were then 


\section{International Journal of Oceanography \& Aquaculture}

embedded in flat embedding moulds and kept in an oven at $60^{\circ} \mathrm{C}$ for 48 hours for polymerization [28].

Once the polymerization completed, semithin sections of $0.5 \mu$ thickness were cut under a UC 7 Ultramicrotome (Leica Microsystems, Germany), stained with $1 \%$ toluidine blue and examined under a Leica DM 500 Research Microscope with Dewinter camera attachment and Biowizard software for light microscopic observations. Measurements of cells nuclei, nucleoli and cytoplasmic granulations were recorded. For ultrastructural studies, $60 \mathrm{~nm}$ thick sections cut on the ultramicrotome were collected on copper grids and stained with uranyl acetate followed by lead citrate. The stained sections mounted on copper grids were scanned under a JEM 1400 Plus Transmission Electron Microscope (JEOL, Japan) operating at 60KV. Selected regions were captured using a Gatan SC 1000B CCD camera and the electron micrographs were analyzed for fine structural details. Dimensions of the organelles were calculated using the scale bar.

\section{Results}

The female reproductive cycle in T. schirnerae was largely divided into three phases: pre-reproductive, reproductive and post-reproductive phases. The prereproductive phase extended from July to September wherein the ovaries appeared as creamy white, thin bands with no signs of yolk deposition. The reproductive season commenced with the onset of vitellogenesis (yolk deposition in oocytes) in October. The ovary has a bulged appearance packed with yellow-orange oocytes. The postreproductive season began at the end of March when ovigerous females were apparent in the population and ended in June. The ovary has a flabby appearance filled with atretic oocytes and shrunken follicles during this period.

\section{Light Microscopic Observations}

Light microscopic observations of semithin sections of the MO revealed a cyclic change in structure in accordance with the phases of reproduction. The activity of MO was found minimum during the pre-reproductive season, reached its peak during the reproductive phase followed by a decline in the post-reproductive phase. A clear parallelism was observed between the volume of MO cell cytoplasm and nucleus and the reproductive phases.

Pre-reproductive phase: The gland appeared small (length $687.21 \pm 135.54 \mu \mathrm{m}$ and width $361.16 \pm 43.24 \mu \mathrm{m}$ ), composed of compactly packed small, oval uniform sized cells $(11.78 \pm 5.10 \mu \mathrm{m})$ not arranged in cords. Their centrally placed oval to spherical nuclei $(5.51 \pm 1.08 \mu \mathrm{m})$ appeared mildly basophilic with 1 to 2 nucleoli seen attached to the inner nuclear membrane. The cytoplasm was mildly basophilic with a few granulations $(0.75 \pm 0.28$ $\mu \mathrm{m})$. The cells were seen surrounded by narrow capillaries, enclosing a few hemocytes within them (Figures 1A-B).

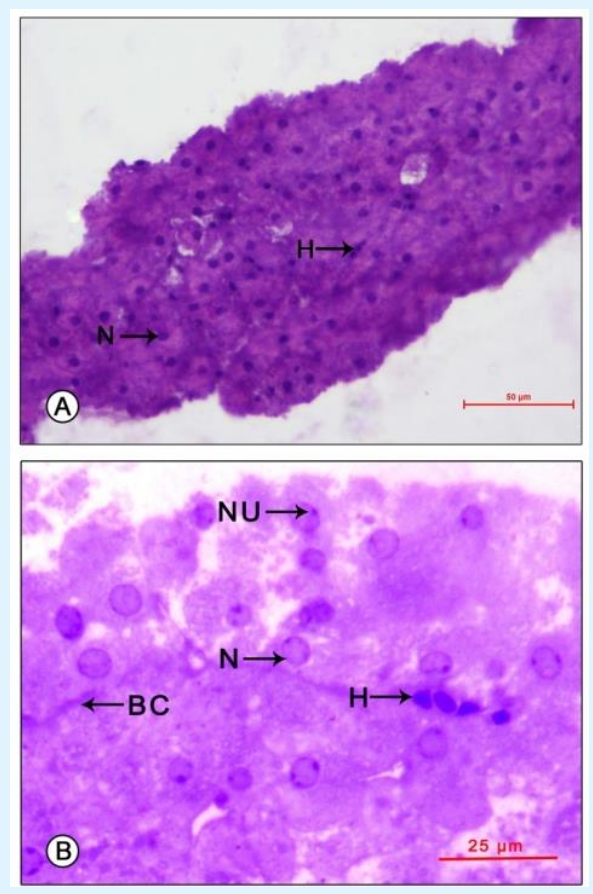

Figure 1: Light micrograph of mandibular organ of Travancoriana schirnerae during pre-reproductive phase (July).

(A) Mandibular organ composed of compactly packed cells without cord-like arrangement. (B) Gland cells at higher magnification showing spherical nuclei with nucleoli and narrow capillaries enclosing a few hemocytes.

BC: Blood capillary; H: Hemocytes; N: Nucleus; NU: Nucleolus.

Reproductive phase: The gland has a hypertrophied appearance (length 1033.03 $\pm 127.60 \mu \mathrm{m}$ and width $597.33 \pm 128.54 \mu \mathrm{m})$, composed of a heterogenous population of cells. At the point of attachment to the adductor muscle of the mandible, the organ was composed of compactly packed rectangular cells (type I cells-17.61 $\pm 1.63 \mu \mathrm{m}$ ) arranged in cords. Their large spherical nuclei $(6.25 \pm 1.04 \mu \mathrm{m})$ were eccentric in 


\section{International Journal of Oceanography \& Aquaculture}

position, mostly shifted towards the apical region of the cells. Their transparent nucleoplasm contained 1-2 prominent nucleoli $(0.96 \pm 0.33 \mu \mathrm{m})$ arranged peripherally. The lightly stained cytoplasm carried medium sized granulations $(1.43 \pm 0.51 \mu \mathrm{m})$. The cords of cells were seen surrounded by large sinuses and capillaries with copious number of granular and a few agranular hemocytes. Towards the other half, the organ was composed of loosely packed large oval cells (type II cells-23.33 $\pm 4.73 \mu \mathrm{m}$ ), not arranged in cords. Their large spherical nuclei $(7.86 \pm 2.50 \mu \mathrm{m})$ occupied an eccentric position with 1-2 distinct nucleoli $(1.34 \pm 0.31 \mu \mathrm{m})$, attached to the inner nuclear membrane. Both the nucleoplasm and cytoplasm were mildly basophilic with the cytoplasm filled with numerous large granulations $(2.21 \pm 0.92 \mu \mathrm{m})$ (Figures 2A-B; 3).

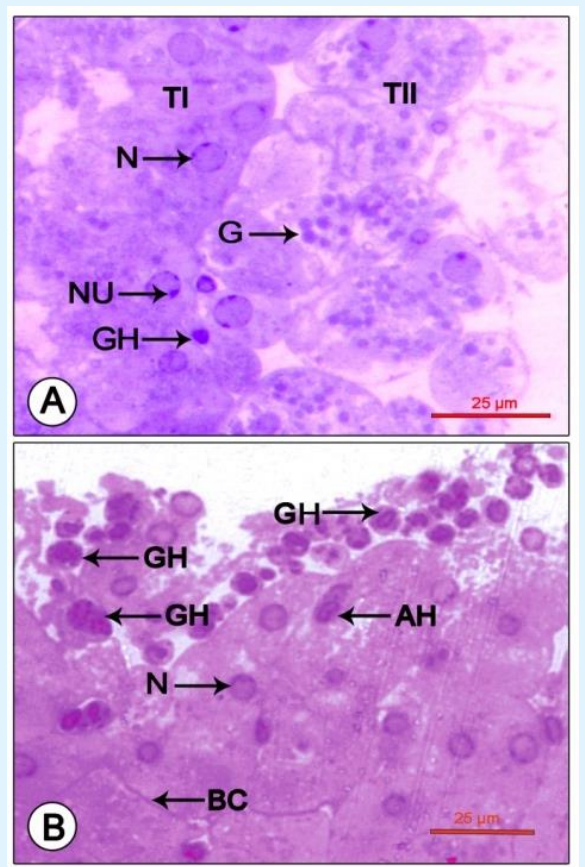

Figure 2: Photomicrograph showing mandibular organ during the reproductive phase (December).

(A) Mandibular organ with compactly packed type I cells and loosely arranged type II cells enclosing prominent nuclei with nucleoli and cytoplasmic granulations. (B) Mandibular organ displaying copious granular and a few agranular hemocytes in large blood sinuses.

AH: Agranular hemocyte; BC: Blood capillary; G: Cytoplasmic granule; GH: Granular hemocyte; N: Nucleus; NU: Nucleolus; TI: Type I cell; TII: Type II cell

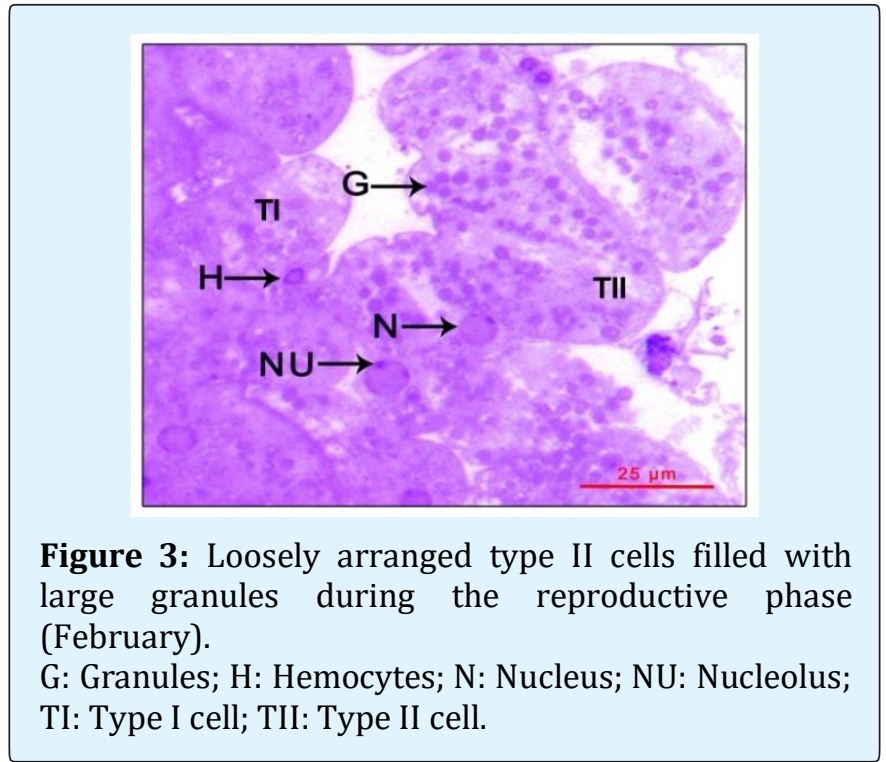

Post-reproductive phase: The gland cells $(12.21 \pm 5.67$ $\mu \mathrm{m})$ and their nuclei $(5.08 \pm 1.19 \mu \mathrm{m})$ have a hypotrophied appearance showing no signs of activity (gland size length $817.05 \pm 101.76 \mu \mathrm{m}$ and width $482.86 \pm 170.77 \mu \mathrm{m}$ ). The cord like arrangement was there without regional distinction between the cell types. Both the cytoplasm and nucleoplasm exhibited moderate basophilia with a reduction in the number and size of cytoplasmic granulations $(1.25 \pm 0.44 \mu \mathrm{m})$. Blood sinuses and capillaries were indistinct with sparsely distributed granular and agranular hemocytes (Figure 4).

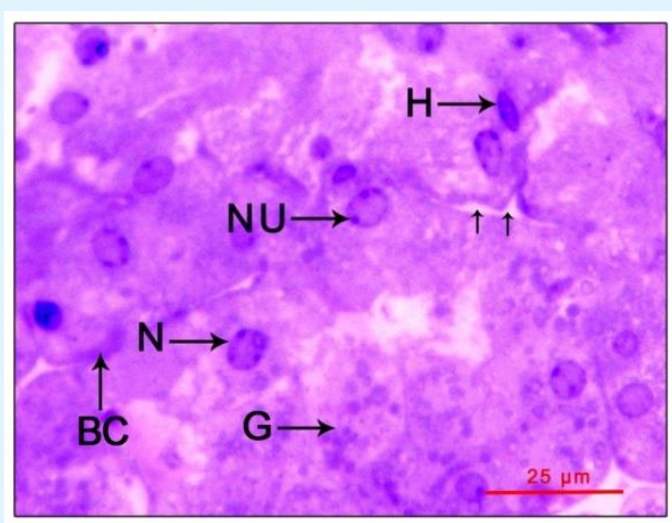

Figure 4: Mandibular organ of post-reproductive phase (April) showing comparatively smaller cells with few granulations and indistinct blood capillaries enclosing few hemocytes.

BC: Blood capillary; G: Granules; H: Hemocytes; N: Nucleus; NU: Nucleolus;

Arrows indicates blood sinus. 


\section{International Journal of Oceanography \& Aquaculture}

\section{Ultrastructural Observations}

Pre-reproductive phase: The gland cell cytoplasm was characterized by numerous polymorphic mitochondria, dilated vesicles of rough endoplasmic reticulum (RER) and free ribosomes. Profiles of smooth endoplasmic reticulum (SER) and Golgi were inconspicuous or rare. The mitochondria were small in size $(0.33 \pm 0.08 \mathrm{~nm})$ and of varied shapes: oval, round or rod shaped and often possessed a matrix of intermediate density and moderately small number of transversely arranged tubular cristae. The karyoplasm contained a few patches of heterochromatin and 1 or 2 nucleoli dispersed along the nuclear envelope (Figures 5A-B). Two distinct types of hemocytes were identified in the hemolymph channels and sinuses: granulocytes and agranulocytes (Figures 6AB). No signs of secretory activity were perceptible in the gland cells. Free ribosomes were seen dispersed randomly in the cytoplasm.

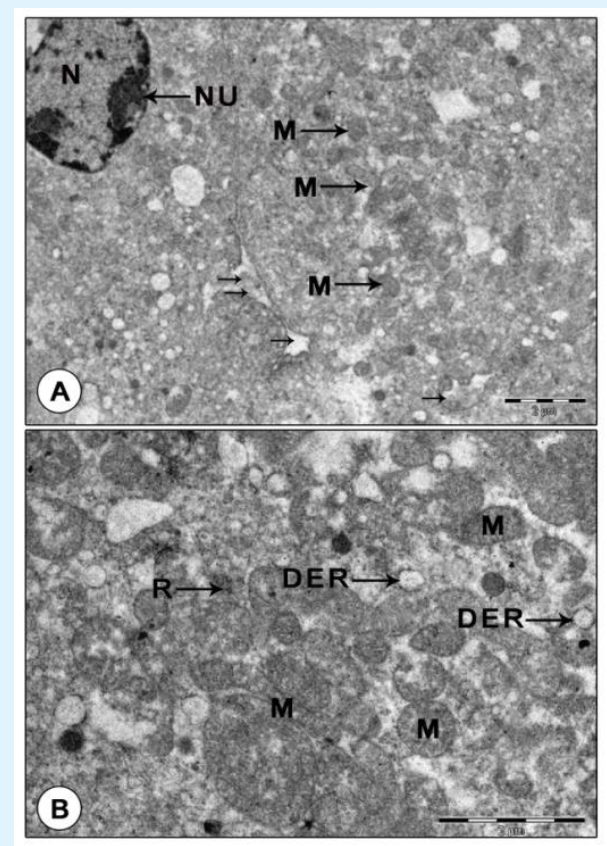

Figure 5: Transmission electron micrograph of mandibular organ cells during pre-reproductive phase (July).

(A) Gland cells displaying nucleus with nucleoli, many small oval to elongate mitochondria and dilated RER vesicles. Note the blood sinuses between the gland cells. (B) A portion of the gland cell enlarged illustrating mitochondria with indistinct cristae.

DER: Dilated RER cisternae; M: Mitochondria; N: Nucleus; NU: Nucleolus; R: Ribosomes;

Arrows indicates the blood sinuses.
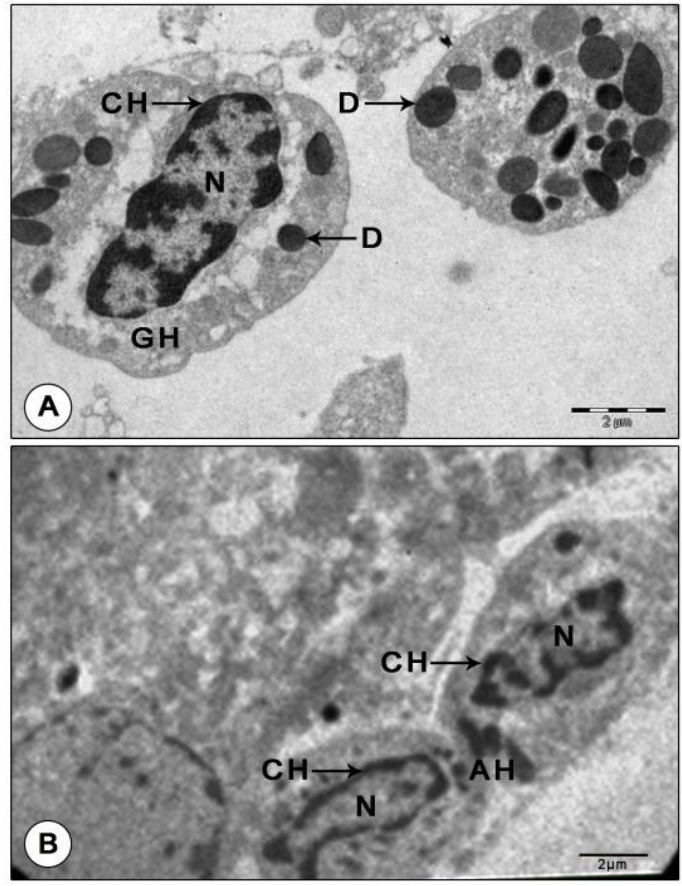

Figure 6: Granular and agranular hemocytes in mandibular organ during pre-reproductive phase.

(A) Granulocyte with electron Dense granules. (B) Agranular hemocytes in a blood capillary adjoining the gland cells.

AH: Agranulocyte; CH: Chromatin; D: Dense granule; GH: Granulocyte; N: Nucleus

Reproductive phase: Transmission electron microscopic observations revealed that the organ cells showed remarkable changes during the reproductive phase. The MO cells were in their highest state of activity, characterized by the presence of large spherical nuclei and abundant cytoplasm with numerous giant, unusually dense, polymorphic mitochondria, RER, SER, Golgi complexes, free ribosomes and secretory granules. The abundant cytoplasm was filled with extraordinarily hypertrophied, dense, unusual shaped: elongate, ring, cup, rod, dumbbell or C- shaped mitochondria (up to $2 \mu \mathrm{m}$ ). Concentric rings of mitochondria arranged one inside the other were perceptible in some gland cells. These mitochondria were densely packed with transverse tubular cristae (Figures 7A-C). Proliferation of cristae was evident in some hypertrophied mitochondria (Figure 8A). 


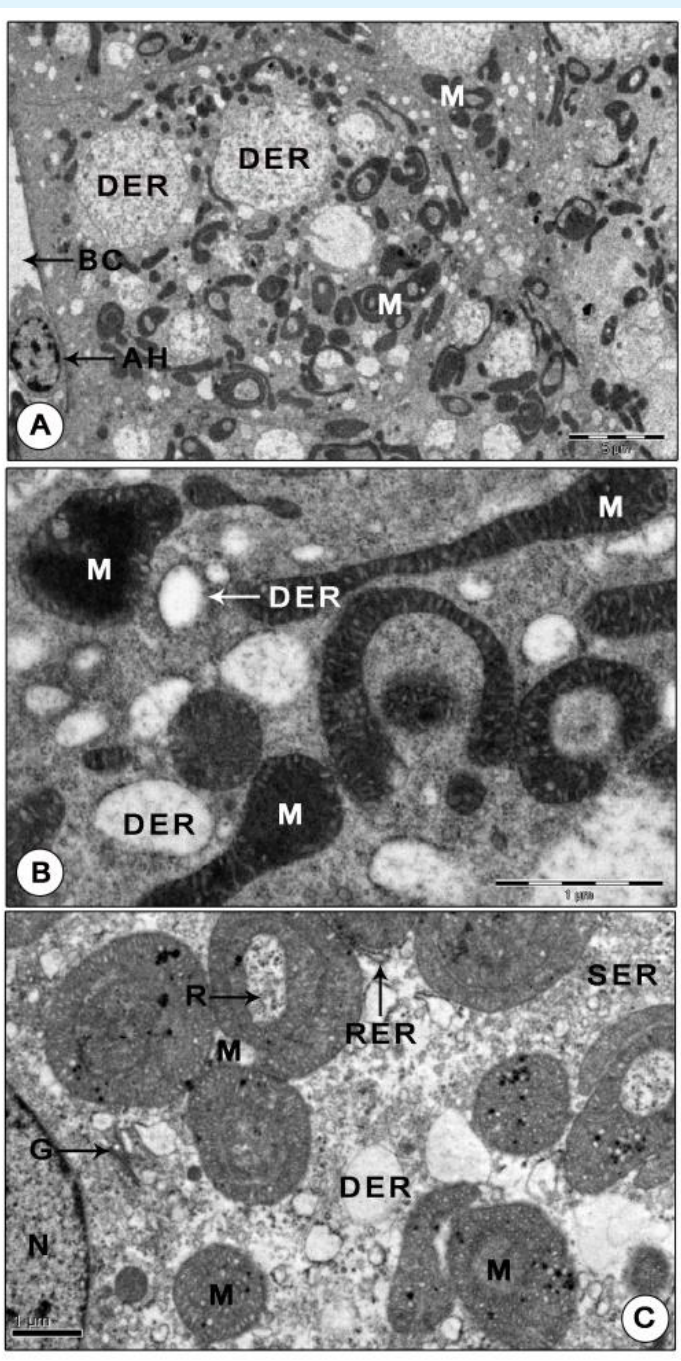

Figure 7: Ultrastructure of mandibular organ during reproductive phase.

(A) Gland cells displaying numerous unusual shaped highly dense polymorphic mitochondria, large dilated RER vesicles enclosing coarse granular materials (December). (B) Portion of the gland cell portraying extraordinarily dense, round, elongate, dumbbell, Cshaped mitochondria and RER vesicles (December). (C) Gland cell showing giant mitochondria arranged in concentric rings, Golgi complex, clusters of SER vesicles and RER (February). Note the free ribosomes trapped in the cytoplasmic matrix within the concentric ring. AH: Agranular hemocyte; BC: Blood capillary; DER: Dilated RER cisternae; G: Golgi body; M: Mitochondria; N: Nucleus; R: Ribosomes; RER: Rough endoplasmic reticulum; SER: Vesicles of SER.

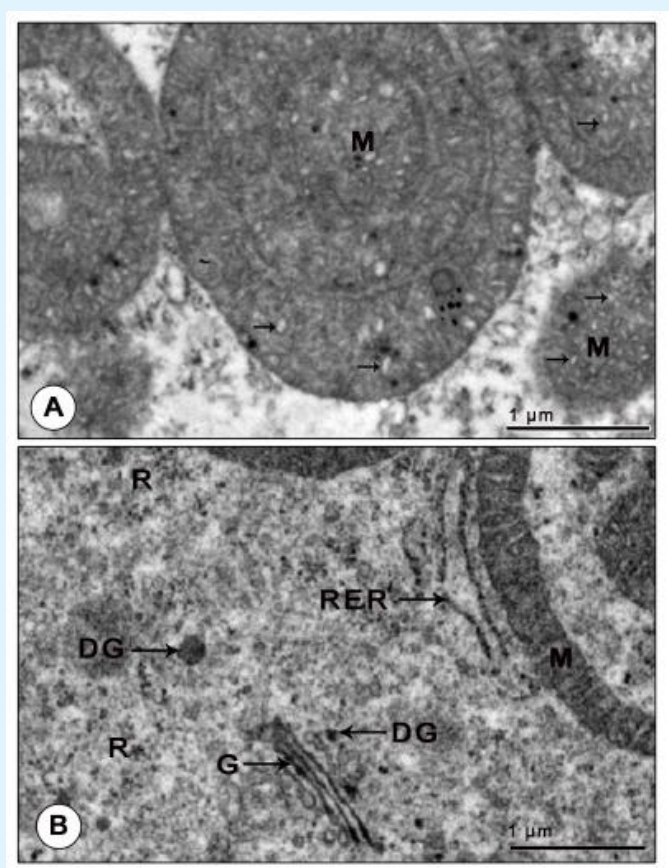

Figure 8: Electron micrograph of mandibular organ during reproductive phase (February).

(A) Mitochondria with proliferation of cristae. (B) Well developed Golgi complex with cisternae, vesicles and scattered dense granules and swollen tubular RER cisternae adjoining the ring shaped mitochondria.

DG: Dense granule; G: Golgi body; M: Mitochondria; R: Ribosomes; RER: Rough endoplasmic reticulum. Arrows indicates the proliferation of cristae.

The RER appeared in two morphological forms: either as swollen tubular cisternae or as dilated vesicles filled with some moderately dense or lucent, fine or coarse granular material. Tubular cisternae of RER were seen in close association with the hypertrophied mitochondria. Profiles of Golgi consisting of parallel stacks of cisternae, small vesicles and dense granules lie in the immediate vicinity of the mitochondria, dilated cisternae and vesicles of RER and SER. The swollen cisternae of Golgi encompassed moderate amounts of some electron dense material and the dense granules of Golgi were found strewn throughout the cytoplasm (Figure 8B). The cytoplasm was richly supplied with free ribosomes. Clusters of free ribosomes were seen trapped in the cytoplasmic matrix between the concentric rings of mitochondria. A notable change in the gland cells of the reproductive phase was the presence of homogenously dense spheroid secretory granules $(0.34 \pm 0.15 \mu \mathrm{m})$ which 


\section{International Journal of Oceanography \& Aquaculture}

possibly may contain MF, the secretory product of MO (Figure 9A).
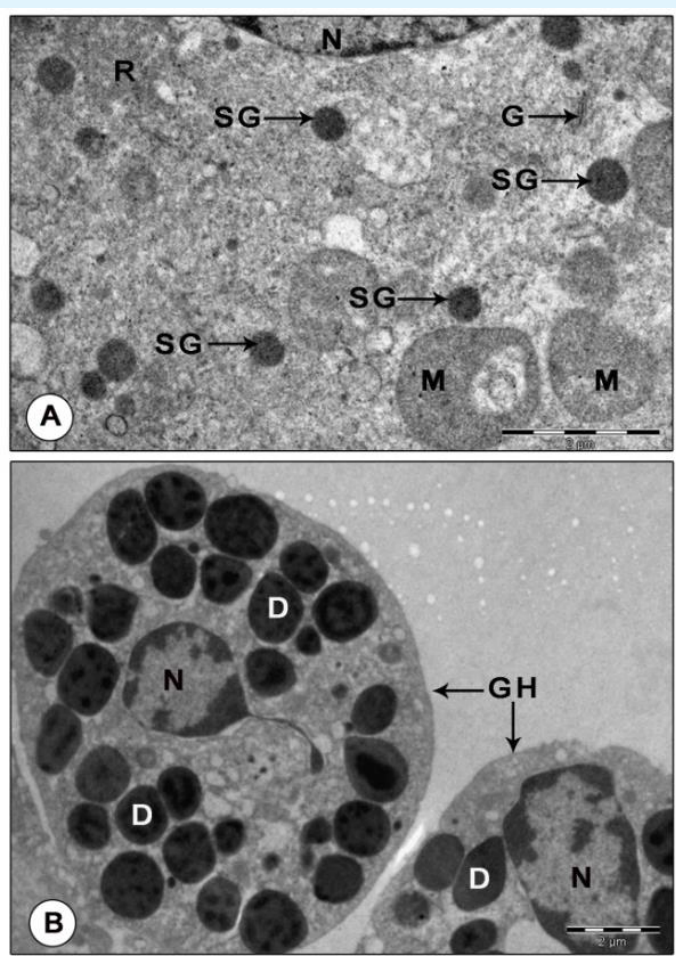

Figure 9: Electron micrograph of mandibular organ during reproductive phase (February).

(A) Gland cell illustrating homogeneously dense spherical secretory granules (B) Granular hemocytes filled with electron dense granules of varied size and shape.

D: Dense granule; G: Golgi body; GH: Granulocytes; M: Mitochondria; N: Nucleus; R: Ribosomes; SG: Secretory granule.

Another prominent feature of MO of reproductive phase was the abundance of granular hemocytes in the wide hemolymph channels and sinuses surrounding the gland cells. The granulocytes have large oval or irregularly shaped nuclei with patches of heterochromatin along the inner nuclear membrane and also seen dispersed in the karyoplasm. Their cytoplasm was comprised of variously shaped: round, spherical, elongate, rod or pear shaped granules of intermediate density enclosing dense cores and lucent peripherals. Organelles like a few mitochondria, SER vesicles and cisternae of RER were found scattered in the cytoplasm. Agranulocytes were elongate cells with large, oval nuclei enclosing dense patches of chromatin along the peripheral karyoplasm and scarce cytoplasm. The cytoplasm contained organelles like mitochondria with parallel cristae, vesicles of SER and free ribosomes, but devoid of granules (Figure 9B).

Post-reproductive phase: The gland showed no signs of activity. The profiles of Golgi, RER and SER were indistinct. Free ribosomes were sparsely distributed in the cytoplasm. Mitochondria were rather inconspicuous, lost their giant appearance. Small $(0.66 \pm 0.07 \mu \mathrm{m})$ and dense mitochondria with sparse cristae and indistinct limiting membranes were encountered in a few MO cells. Chromatin arranged in the form of a thin rim along the peripheral nucleoplasm. No secretory granules were noticed in MO during this stage (Figures 10A-B).

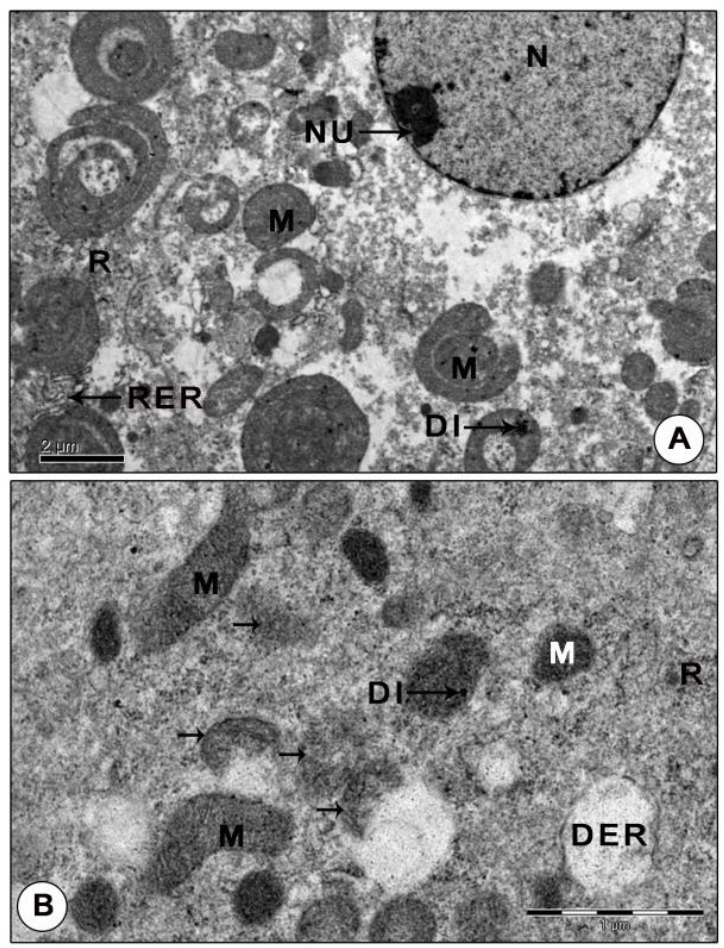

Figure 10: Ultrastructure of mandibular organ during post-reproductive phase (April).

(A) Gland cell showing polymorphic mitochondria with indistinct cristae, sparsely distributed free ribosomes and narrow tubular RER cisternae. (B) Mitochondria with indistinct cristae and limiting membrane showing signs of inactivity.

DER: Dilated RER cisternae; DI: Dense inclusions; M: Mitochondria; N: Nucleus; NU: Nucleolus; R: Ribosomes; RER: Rough endoplasmic reticulum. Arrows indicates degenerating mitochondria. 


\section{International Journal of Oceanography \& Aquaculture}

\section{Discussion}

The light and electron microscopic observations of the MO of the freshwater crab T. schirnerae revealed that the gland cells underwent correlative changes in accordance with the female reproductive cycle as evidenced from hypertrophy of the gland cells and nuclei, prominence of mitochondria, Golgi, dilated cisternae and vesicles of RER and SER, free ribosomes and secretory granules during the reproductive phase. The activity of MO was found parallel to the stages of reproduction with highest activity during the reproductive phase and least during the pre and post-reproductive phases which was in agreement with the findings of Le Roux [1] in C. maenas, Hinsch [2] in L. emarginata and Navya and Sudha Devi [29] in Barytelphusa cunicularis.

In the current research, the gland cells and nuclei had a hypertrophied appearance during the reproductive phase and a hypotrophied appearance during the pre and post-reproductive seasons. Similarly, Byard, et al. [5], Couch, et al. [30] and Waddy, et al. [31] observed an increase in MO size during ovarian maturation in Homarus americanus. In P. clarkii and S. quadratum, a progressive increment in size of the MO could be noticed with progress in development of the ovary $[20,32]$. The weight of the MO increased with the advancement of reproductive stage in female $O$. senex senex [19]. In Paratelphusa sp. and B. cunicularis, the MO appeared small during the non-reproductive phase and attained maximum size during the reproductive season $[21,29]$. The hypertrophied nature of the gland cells during the reproductive phase can be attributed to the increased volume of cytoplasm and nuclei which in turn indicates increased activity of the cell. The swelling of nucleus is linked to the increased transcription of mRNA for translation of proteins (enzymes) necessary for the synthesis of MF.

In $T$. schirnerae, the gland cells displayed numerous giant mitochondria of varied size, shape and density and with increased number of tubular cristae during the reproductive phase, which are characteristics of high cellular activity [33,34]. Similar to our study, mitochondria exhibited unusual shapes in the MO of mature female L. emarginata [2]. Sarika, et al. [21] reported the presence of several dense mitochondria in MO of Paratelphusa sp. during the reproductive season. The occurrence of moult related mitochondrial pleomorphism was described in the MO cells of P. clarkii [35]. Besides the typical rod, oval or circular mitochondria, Yudin, et al. [4] depicted rare incidences of large ring shaped mitochondria with concentric rings in MO cells of $C$. sapidus. The presence of giant mitochondria was also demonstrated in the prothoracic gland cells and flight muscles of insects and human endometrial gland cells [36-38]. The prevalence of tubular cristae was a common feature of steroid synthesizing cells [39-41]. Tubular cristae were also reported from corpora allata cells of the insect Locusta migratoria [42]. The abundance of large unusual shaped mitochondria with profuse tubular cristae in MO cells during the reproductive phase indicates their increased state of activity in connection with the production of the terpenoid hormone, MF. The concentric rings of mitochondria suggest their role in cleavage of the cholesterol side chain required for the synthesis of $\mathrm{MF}$ as described for mammalian steroid synthesizing cells [39]. The presence of tubular cristae in the present study may possibly suggest that the MO cells too have a similar function to carry out like the mammalian steroid synthesizing cells such as the testis [43-45].

In $T$. schirnerae, profiles of Golgi were more conspicuous with swollen cisternae, vesicles and dense granules in MO cells during the reproductive phase than at other phases which indicate the involvement of Golgi complexes in packaging the secretory product of the gland cell, the MF. In T. schirnerae, ribosomes were plenty in the gland cells during the reproductive phase, against the reports made by Hinsch and Sarika, et al. $[2,21]$ in the gland cells of female L. emarginata and Paratelphusa sp.

The current study also evidenced the presence of numerous dilated vesicles and swollen tubular cisternae of RER during reproductive phase. Sarika, et al. [21] described extensive networks of RER dispersed throughout the cytoplasm in Paratelphusa sp. gland cells during reproductive season. The predominance of RER, presumably represent the production of enzymes required for the synthesis of MF. The SER was present in rather small amounts, in the form of vesicles, in MO cells of T. schirnerae, against that expected from an organ whose main function was the production of a lipid (terpenoid hormone). On the other hand, SER was a prominent feature in MO cells of reproductively active females of L. emarginata [2], Homarus [5] and Paratelphusa sp. and the steroid producing testicular cells of Pleurodeles waltl [46], corpora allata of L. migratoria and the corpus luteum of rats [47,48]. Christensen [43] observed that the abundance of SER was directly proportional to the amount of cholesterol synthesized in the interstitial cells of guinea pig testis. The reason for the less abundance of SER in the current research may 


\section{International Journal of Oceanography \& Aquaculture}

possibly be attributed to the fact that crustaceans are unable to synthesize cholesterol (the precursor of MF) from acetate; they must get it through their diet. As such, a well-developed SER is not essential for the cell.

Results of this research evinced the presence of electron dense secretory granules in the MO cells during the reproductive phase. Similar results were obtained by Yudin, et al. [4] where they described lipid like inclusions in MO cells of $C$. sapidus. Kraisuwansopit, et al. [27] noticed lipid droplets in the mandibular cells of the sandworm Perinereis $s p$. Johnson, et al. [49] detected lipid droplets in the corpora allata cells of the cockroach Diploptera punctata, where it was a characteristic feature of cells synthesizing juvenile hormone.

This study also witnessed the presence of a great number of hemocytes in $\mathrm{MO}$ cells during the reproductive phase. Similar reports were made by Sarika, et al. [21] in MO of reproductively active females of Paratelphusa $s p$. Hemocytes were frequently encountered in MO of female L. emarginata with vitellogenic ovaries [2]. Huiyang, et al. [50] in Scylla serrata observed indistinct hemolymph sinuses and channels with very few hemocytes during early developmental stages and large blood sinuses with profusely dispersed hemocytes in later developmental stages. It is proposed that the occurrence of copious hemocytes, in particular, granulocytes with electron dense granules of varying sizes, shapes and density in MO cells during the reproductive season reflect the functional state of the gland cells and the role of these hemocytes in the storage and transport of the secretory product of the gland.

\section{Conclusion}

Fine structural analysis of MO cells in the freshwater crab T. schirnerae revealed that the gland underwent correlative changes in accord with the seasons of the female reproductive cycle as evidenced from hypertrophy of gland cells and their nuclei, prominence of mitochondria, Golgi, RER, SER and free ribosomes, secretory granules and hemocytes during the reproductive phase. Future research involving gene expression studies are required to address the exact mode of action of the hormone released by the organ in accelerating reproduction in female freshwater brachyurans.

\section{Conflicts of Interest}

The authors declare that they have no conflict of interests.

\section{Acknowledgement}

The authors wish to thank the electron microscope facilities provided by the Electron Microscope Laboratory, National Institute of Mental Health and Neurosciences, Bangalore.

\section{Funding}

This work was supported by the Kerala State Council for Science, Technology and Environment [grant number P 115/ 2016/KSCSTE dt. 03-05-2016].

\section{References}

1. Le Roux A (1968) Description of new mandibular organs in decapod crustaceans. C R Acad Sci D 266: 1414-1417.

2. Hinsch GW (1981) The mandibular organ of the female spider crab Libinia emarginata in immature, mature and ovigerous crabs. J Morph 168(2): 181187.

3. Aoto T, Kamiguchi Y, Hisano S (1974) Histological and ultrastructural studies on the $\mathrm{Y}$ organ and the mandibular organ of the freshwater prawn Palaemon paucidens, with special reference to their relation with the moulting cycle. J Fac Sci Hokkaido Univ 19(2): 295-308.

4. Yudin AI, Diener RA, Clark Jr WH, Chang ES (1980) Mandibular gland of the blue crab, Callinectes sapidus. Bio Bull 159(3): 760-772.

5. Byard EH, Shivers RR, Aiken DE (1975) The mandibular organ of the lobster, Homarus americanus. Cell Tissue Res 162(1): 13-22.

6. Hinsch GW, Al Hajj H (1975) The ecdysial gland of the spider crab, Libinia emarginata (L). J Morph 145(2): 179-188.

7. Couch EF, Adejuwon CA, Segal S, Koide SS (1978) Ultrastructural study and radio immunological evidence for progesterone production in the mandibular gland of the lobster (Homarus americanus). Bio Bull 155(2): 433.

8. Hinsch GW (1977) Fine structural changes in the mandibular gland of the male spider crab Libinia emarginata (L.) following eyestalk ablation. J Morph 154(2): 307-316. 


\section{International Journal of Oceanography \& Aquaculture}

9. Laufer H, Landau M, Borst D, Homola E (1986) The synthesis and regulation of methyl farnesoate, a new juvenile hormone for crustacean reproduction. Advances in Invertebrate Reproduction 4: 135-143.

10. Laufer H, Borst D, Baker FC, Reuter CC, Tsai LW, et al. (1987) Identification of a juvenile hormone-like compound in a crustacean. Science 235(4785): 202205.

11. Reddy PS, Ramamurthi R (1998) Methyl farnesoate stimulates ovarian maturation in the freshwater crab Oziotelphusa senex senex Fabricius. Curr Sci 74(1): 6870.

12. Waddy SL, Aiken DE (2000) Endocrinology and the culture of homarid lobsters. In: Fingerman, Nagabhushanam, (Eds.), Recent advances in marine biotechnology. Science Publishers, USA.

13. Buchholz C, Adelung D (1980) The ultrastructural basis of steroid production by the $\mathrm{Y}$ organ and the mandibular organ of the crabs Hemigrapsus nudus (Dana) and Carcinus maenas L. Cell Tissue Res 206(1): 83-94.

14. Hinsch GW (1980) Effect of mandibular organ implants upon the spider crab ovary. Trans Amer Micros Soc 99(3): 317-322.

15. Taketomi Y, Kawano Y (1985) Ultrastructure of the mandibular organ of the shrimp, Penaeus japonicus, in untreated and experimentally manipulated individuals. Cell Biology and International Reproduction 9(12): 1069-1074.

16. Vijayan KK, Diwan AD (1994) The mandibular organ of the prawn Penaeus indicus H. Milne Edwards and its inconsequential role in moulting process. Journal of Aquaculture and Biology 9: 45.

17. Sheng Li, Wei-Xin Z (1999) Structural changes of mandibular organ during the ovary developing cycle in crayfish. J Shanghai Fish Univ.

18. Sheng Li, Wei-Xin Z, De-Shang L, Cong-Hai Y (2001) Profile of progesterone and estradiol in hepatopancreas, ovary and hemolymph of shrimp Penaeus chinensis during reproductive cycle. Journal of Fisheries Science China 25(4): 304-310.

19. Nagaraju GPC, Reddy PR, Reddy PS (2004) Mandibular organ, its relation to body weight, sex, moult and reproduction in the crab Oziotelphusa senex senex Fabricius (1791). Aquaculture 232(1-4): 603-612.

20. Syama VP (2009) Studies on hormonal regulation of growth and reproduction in decapods crustaceans, $\mathrm{PhD}$ thesis, Kannur University, India.

21. Sarika SN, Gayathri N, Anilkumar G (2014) Secretory activity of mandibular organ fluctuates in response to reproductive season of the field crab Paratelphusa $s p$. (Brachyura; Decapoda): an ultrastructural study. Zool Stud 53: 65.

22. Borst DW, Laufer H, Landau M, Chang ES, Hertz WA, et al. (1987) Methyl farnesoate and its role in crustacean reproduction and development. Insect Biochem 17(7): 1123-1127.

23. Teal PE, Jones D, Jones G, Torto B, Nyasembe $V$, et al. (2014) Identification of methyl farnesoate from the hemolymph of insects. J Nat Prod 77(2): 402-405.

24. Laufer H, Biggers WJ, Ahl JS (1998) Stimulation of Ovarian maturation in the crayfish Procambarus clarkii by methyl farnesoate. Gen Comp Endocrinol 111(2): 113-118.

25. Nagaraju GPC, Reddy PR, Reddy PS (2006) In vitro methyl farnesoate secretion by mandibular organs isolated from different moult and reproductive stages of the crab Oziotelphusa senex senex. Fisheries Sci 72(2): 410-414.

26. Nagaraju GPC (2011) Reproductive regulators in decapod crustaceans: an overview. J Exp Biol 214(1): 3-16.

27. Kraisuwansopit A, Limsakul S, Mahasawasde S, Meunpol O (2008) Ultrastructure of sesquiterpenoid and eicosanoid producing organ from sandworm (Perinereis sp.) and effect of the extracts on marine shrimp ovarian maturation. $4^{\text {th }}$ Kasetsart University Annual Conference Bangkok, Thailand.

28. Frasca JM, Parks VR (1965) A routine technique for double-staining ultrathin sections using uranyl and lead salts. J Cell Biol 25(1): 157-161.

29. Navya G, Sudha Devi AR (2018) Morphology and histology of mandibular organ in relation to growth and reproduction in the freshwater crab Barytelphusa 


\section{International Journal of Oceanography \& Aquaculture}

cunicularis. International Journal of Oceans and Oceanography 12(2): 93-109.

30. Couch EF, Adejuwon CA, Koide SS (1979) Production and metabolism of steroids in Homarus americanus. Biol Bull 157: 364.

31. Waddy SL, Aiken DE, de Kleijn DPV (1995) Control of growth and reproduction. In: Factor JR, (Ed.), In Biology of the lobster, Homarus americanus. Academic Press, San Diego, California, pp: 217-266.

32. Wei-Xin Z, Jian-Feng LU (2004) Development and ultrastructure of mandibular organ in precocious and normal Chinese mitten crab Eriocheir sinensis. J Shanghai Fish Univ.

33. Watanabe Y (1957) Intra-cytoplasmic sac or cytoplasmic filamentous structure of cells. Symp Soc Cell Chem 5: 35-52.

34. Kahri AI (1968) Effects of actinomycin D and puromycin on the ACTH-induced ultrastructural transformation of mitochondria of cortical cells of rat adrenals in tissue culture. J Cell Biol 36(1): 181-195.

35. Taketomi Y, Nakano Y (2007) Y-organ and mandibular organ of the crayfish Procamburus clarkii during the moult cycle. Crustacean Research 36: 2536.

36. Beaulaton JA (1968) Ultrastructural changes in the cell walls of the prothoracic gland of silkworms during the last two years. I. chondrioma and its relations with the agrarian reticulum. J Cell Biol 39: 501-525.

37. Sohal RS, McCarthy JL, Allison VF (1972) The formation of 'giant' mitochondria in the fibrillar flight muscles of the house fly, Musca domestica L. J Ultrastruct Res 39(5): 484-495.

38. Coaker T, Downie T, More IAR (1982) Complex giant mitochondria in the human endometrial glandular cell: serial sectioning, high-voltage electron microscopic and three-dimensional reconstruction studies. J Ultrastruct Res 78(3): 283-291.

39. Christensen AK, Gillim SW (1969) The correlation of fine structure and function in steroid secreting cells with emphasis on those of the gonads. In: Kerns KW, (Ed.), The gonads. Appleton-Century Crofts, New York.
40. Nussdorfer GG (1980) Cytophysiology of the adrenal zona glomerulosa. Int Rev Cytol 64: 307-368.

41. Haget A, Ressouches A, Rogueda J (1982) Ultrastructural detection of endocrine activities in the ventral glands of the head of Carausius (Phasmida: Lonchodidae) during embryonic development. Int J Insect Morphol Embryol 11(2): 99-108.

42. Joly L, Porte A, Girardie A (1967) Caractere ultrastructuraux des corpora allata actifs et inactifs chez Locusta migratoria. C R Acad Sci D 265: 16331635.

43. Christensen AK (1965) The fine structure of testicular interstitial cells in guinea pigs. J Cell Biol 26(3): 911935.

44. Friend DS, Brassil GE (1970) Osmium staining of endoplasmic reticulum and mitochondria in the rat adrenal cortex. J Cell Biol 46(2): 252-266.

45. Enders AC (1973) Cytology of the corpus luteum. Biol Reprod 8: 158-182.

46. Picheral B (1968) Ultrastructure of the cells of the glandular tissue of the testis of Pleurodeles waltl Micah. J Microsc 7: 115-134.

47. Joly L, Joly P, Porte A, Girardie A (1968) Physiological and ultrastructural study of the corpora allata of Locusta migratoria L. (Orthoptere) in the Greek phase. Arch Zool Exp Genet 109: 703-728.

48. Enders AC, Lyons WR (1964) Observations on the fine structure of lutein cells. II. The effect of hypophysectomy and mammotrophic hormone in the rat. J Cell Biol 22: 127-141.

49. Johnson GD, Stay B, Rankin SM (1985) Ultrastructure of corpora allata of known activity during the vitellogenic cycle in the cockroach Diploptera punctata. Cell tissue Res 239(2): 317-327.

50. Huiyang H, Shaoqing L, Haihui Y, Guizhong W (2003) Histological study on the development of the mandibular organ of the mud crab Scylla Serrata. Marine Sciences 27(2): 49-52.

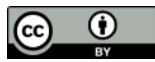

Sudha Devi AR, et al. Light and Electron Microscopic Studies on Mandibular Organ in Relation to Female Reproductive Cycle of the Freshwater Crab Travancoriana Schirnerae. Int J Oceanogr Aquac 2019, 3(3): 000173.
Copyright $($ Sudha Devi AR, et al. 